\title{
Systematization of the Mineral Raw Material Waste Recycling Process
}

\author{
Anatoly Bardovsky ${ }^{1, *}$, Ilnur Basyrov ${ }^{1}$, and Liliya Valeeva $^{1}$ \\ ${ }^{1}$ National University of Science and Technology “MISiS”, Leninskiy prospekt, 4, Moscow, 119049, Russia
}

\begin{abstract}
The paper considers a system for optimizing the recycling process of mineral raw material waste in terms of the target function, which takes into account economic, technological, and environmental criteria. We have suggested a structural model of the production process of mineral raw material recycling using cost flows. Based on the analysis of this model, we concluded on the need to develop new methods for assessing and choosing the parameters of the equipment used, including specific performance criteria to assess the degree of sophistication of the systems under study.
\end{abstract}

The economic system based on a planned economy predetermined a one-sided development of the mining industry in the previous century, aimed exclusively at extracting valuable rocks from the mined raw materials. Waste left over from mining and processing was usually stored, which resulted in its huge amounts accumulated across the country. Therefore, the issue of recycling technogenic raw materials has now become an independent problem, the solution to which is of great importance for Russia [1]. In this regard, the stages of system analysis of waste-free technology are also applicable to a system analysis of methods for recycling technogenic raw materials, except for the stages related to the assessment, production, and processing of primary (basic) raw materials.

The first stage in creating a method for recycling mineral raw material waste should be the analysis of its component and mineral composition. Waste recycling and an intersectoral manufacture of products from the same require a feasibility study of the needs of a particular region for additional products. In particular, the Central Regional Geological Center has carried out such studies on mineral raw materials, waste, and quarry overburden of the Glavmosstroy company to use them as raw materials and to replace imported raw materials in the construction and other industries in Moscow [2]. The analysis of these studies convincingly proved the possibility of waste recycling to manufacture a wide range of products for the construction industry and other sectors of the national economy.

Currently, there are little opportunities for launching waste recycling at the industry or factory level due to the underdevelopment of marketing relations and weakening economic mechanisms. In our opinion, the most promising are the levels of a concentration plant, a quarry head office, and a production process, since the costs of launching the production and sales are incomparable with similar costs at the upper levels of the hierarchy, which is very significant for the developing economy of Russia.

\footnotetext{
*Corresponding author: bardowski@yandex.ru
} 
Considering the waste processing technology as a system aimed at using waste as a raw material, its disposal, and improving the environment situation, we can conclude that a formalized description of such systems should involve technological, economic, and environmental criteria. Depending on the level of the waste recycling method hierarchy, the composition of these criteria may vary. Therefore, the problem of optimal planning of waste recycling method is essentially a multipurpose optimization problem, which should take into account all the variety of technological options and criteria for their assessment that are used when choosing a specific process method.

In order to launch a mineral raw material waste recycling method at a regional level, we should have information about needs for building materials and other products that can be obtained from waste. We also need information about the amount of waste accumulated by an enterprise and the possibility of full or partial replacement of traditional raw materials for building materials with waste [3].

In general, the mineral raw material waste recycling method is optimized by determining the values of the following target function:

$$
\ni=\Phi\left(R, T, p, m, \ell, k, S_{\ell i}, S_{k j}, Z, q, \sigma, \varepsilon, 3, Ц\right),
$$

where $\ni$ is the optimality criterion; $R$ is a set of indicators characterizing the size and physical and mechanical properties of waste (particle size, moisture content, strength, contamination with clay and silty impurities, etc.); $T$ is the type of waste recycling process scheme; $p$ is the parameters of cleaning equipment; $m$ is parameters of drying equipment; $\ell$ is the parameters of sorting equipment (such as screens and hydraulic or pneumatic classifiers); $k$ is the parameters of grinding equipment (such as mills); $S_{\ell i}$ is the value of operation parameters for the $i^{\text {th }}$ sorting machine (the screen cell size, the screen body vibration parameters, the air flow rate of a pneumatic separator, etc.); $S_{k j}$ is the value of operation parameters for the $j^{\text {th }}$ grinding machine (the number of revolutions or vibrations of the grinding drum; the filling factor of chambers with grinding bodies, etc.); $Z$ is the parameters of mining transport equipment (such an excavator and a dump truck); $q$ is the distance of waste transportation to their recycling place; $\sigma$ is the characteristics of environmental damage and safety exclusion areas; $\varepsilon$ is the amount of damage prevented; 3 is the totality of costs for all stages of the production process by unit of resulting processed products; $Ц$ is the totality of selling prices for various types of recycled products.

Even with relatively simple process flow charts, obtaining waste products of the required quality, in the required amount, and with the minimum costs is possible only by comparing the results of several options characterized by different values of the function variables (1). The prerequisites for optimizing the method is the availability of data on the particle size of waste, impurities, and the configuration of processing equipment. In addition, we need to know the dependence of the equipment performance on the rock quality, the list of variable operating modes of classification and grinding equipment, the data on the process cost parameters, and the costs of various process stages.

Any production system [4-13] has a multilevel hierarchical structure with hierarchical subordination relations defined. The system structure is considered as a set of production facilities united by diverse engineering, technological, economic, and administrative ties.

Several requirements are imposed on such hierarchical structure: the number of levels should be small; isolated subsystems can be considered as independent; an adequate description of each of the subsystems under consideration should cover its most important economic and technological features. The hierarchical structure in the mining and processing industry, depending on the management scale, should be considered in the following way: industry - sub-industry (association) - integrated plant - plant - workshop - process flow process - apparatus [14]. 
Process flow charts for a mining and processing integrated plant, a plant, and a process unit for processing mineral raw materials can be considered as hierarchical structures of various scales. At a sufficiently large scale of such system, even for the flow chart of a process unit consisting of 2 or 3 machines, a variation within a wide range of parameters significantly complicates the search for the optimum. Process flows and processing plants are generally optimized according to economic criteria. The economic efficiency of the raw material processing or waste recycling process is a cumulative indicator, determining a compromise between the product quality, the extraction, the plant performance, and the cost of raw material processing (waste recycling).

However, the joint use of economic, technological, and environmental criteria when optimizing the method for processing mineral raw materials is very difficult due to the virtually complete lack of information on the experience of using such methods. Based on the recommendations by [3] as applied to a non-waste method, economic criteria are decisive, whereas process and environmental criteria should be used for a more accurate selection of the optimal process flow option, if this cannot be done using economic criteria or if two or more compared options are close in terms of economic criteria.

Identifying the optimization criterion taking into account functional relationships between various types of parameters is a very laborious process based on the available experience. There is a relationship between economic and process criteria, that is determined through the price of the resulting products and the cost of processing a unit of raw materials. However, since the waste recycling has an environmental significance, in addition to generally used economic and process criteria, we should take into account such parameters as the damage prevented, the environmental costs, the waste storage and reclamation of the lands occupied by the same, the disposability factor, etc.

The studies $[15,16]$ proved the possibility of taking into account all conflicting criteria in one generalized criterion, which is the main indicator for the economic assessment of any method effectiveness, i.e. the economical effect. With regard to the mineral raw material waste recycling process, we can say that it is defined as the difference between the value of commercial products obtained from waste, the damage prevented, and the costs of obtaining these products, as well as the environmental protection costs.

Thus, the formula for determining the economic effect $\Pi_{i}$ is as follows [3]:

$$
\Pi_{i}=\left[\left(C_{i j}{ }^{\Sigma}+\Sigma Y_{i j}\right)-3_{i}{ }^{\Sigma}\right] \rightarrow \max
$$

where $C_{i j}{ }^{\Sigma}=Q_{i j} L_{j}$ is the total value of the bulk $Q i j$ of the commercial product of the $j^{\text {th }}$ type as per the $i^{t h}$ option, as calculated in prices $L_{j} ; \Sigma Y_{i j}=\Sigma Y_{i j}{ }^{{ }}+\Sigma Y_{i j}{ }^{\mathrm{T}}+\Sigma Y_{i j}{ }^{\mathrm{I}}$ is the total damage prevented from liquid, solid, and dust emissions; $3_{i}{ }^{\Sigma}=3_{i j}+3_{i \text {.пр }}+3_{i \text {.тр }}$ is the total costs, including all costs of production processes and equipment as per the $i^{\text {th }}$ option $\left(3_{i j}\right)$; the environment protection costs $\left(3_{i \text {.пр }}\right)$, and the transport costs $\left(3_{i \text {.тр }}\right)$.

Formula (2) takes into account technological, economic, and environmental criteria. Technological criteria are taken into account in the parameters of waste used for recycling, as well as the amounts of commercial products obtained as a result of such recycling. Economic criteria can be taken into account in the form of such indicators as the cost efficiency, the present costs and profits, etc. The most relevant economic criterion for waste recycling should be considered the criterion of maximum profit or the annual effect, since this is dictated solely by the regional need for additional waste recycling products and, as a rule, by restrictions on capital investments.

However, as stated above, the lack of full information and the impossibility to reliably assess the environmental parameters make it very difficult to determine the economic effect $\Pi_{i}$ based on formula (2).

Mineral raw material waste processing plants, due to their technological features, should be referred to as low-capacity enterprises with an output of finished products not exceeding $50 \ldots 100$ thousand cu.m per year. 
Focusing on the establishment of small enterprises for recycling mineral raw material waste, that are located in the waste accumulation areas, we can argue that, when choosing a particular process flow chart for recycling, the types of equipment used, and its parameters, the costs of environmental protection, production, and transportation are comparable with each other. Therefore, assessing the maximum profit criterion for waste recycling is mainly associated with assessing the costs of production processes and equipment as per the $i^{\text {th }}$ option $3_{i j}$, that is, the technological costs.

In study [17], it is shown that the efficiency of any production process can be assessed by describing it based on the law of conservation of matter and energy. In other words, the most effective is a production process that has balanced resources with a strictly specified operation time of this process. For the production process of waste recycling, resources are understood as: work objects (waste of mineral raw materials), tools (processing machines), the energy used, production facilities (buildings, overpasses), the labor force, etc.

The figure 1 shows a structural model of the production process of mineral raw material processing using cost flows $[18,19]$.

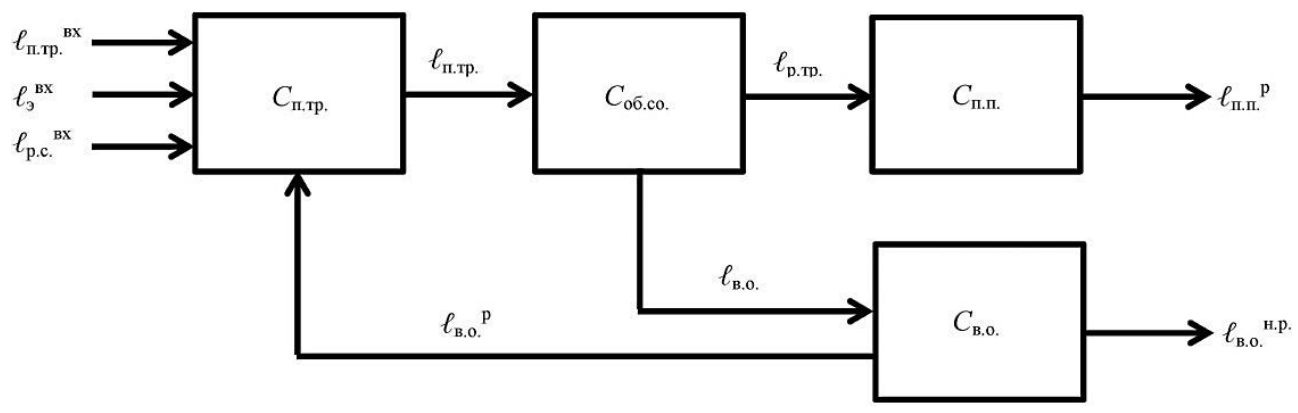

Fig. 1. Structural model of the production process of mineral raw material processing.

A cost flow means the cost of production process elements that enter, function, or exit an operation over a period of time $t_{n} \ldots t_{k}$, where $t_{n}$ is the start of a production process of waste recycling; $t_{k}$ is the end of such process.

In this model, the cost of the production process elements are presented in the form of blocks: the cost of work objects $C_{\text {п.тр. }}$ (e.g., stationary waste); the cost of processing

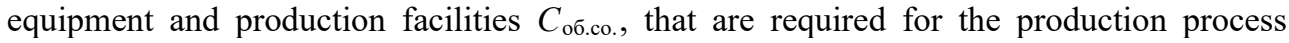
functioning; the cost of finished products of recycling $C_{\text {п.п. }}$; the cost of secondary waste $C_{\text {в.o. }}$ which do not find or partially find industrial use. These blocks are interconnected by material and energy flows $-\ell$, which are reduced to one dimension (rubles/h).

The production process inputs are: the cost flow of work objects (e.g., newly generated waste) $\ell_{\text {п.тр. }}{ }^{\mathrm{Bx}}$, the energy flow $\ell_{3}{ }^{\mathrm{Bx}}$, the labor force flow $\ell_{\text {p.c. }}{ }^{\mathrm{Bx}}$. Between blocks $C_{\text {п.тр }}$. and

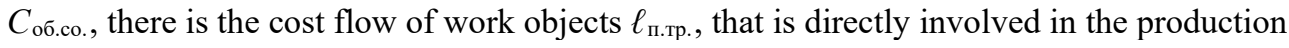
process. At the same time, there may be two options for generating $\ell_{\text {п.тр. }}: \ell_{\text {п.тр. }}>\ell_{\text {п.тр. }}{ }^{\text {вx }}$ due to the use of part of stationary waste $\ell_{\text {п.тр. }}{ }^{\text {ст }}$ and $\ell_{\text {п.тр. }}<\ell_{\text {п.тр. }}{ }^{\text {вx }}$ due to replenishment of stock $\ell_{\text {п.тр. }}{ }^{\text {cт }}$. The $1^{\text {st }}$ option is preferable, since it does not contribute to the accumulation of primary stationary waste.

Between blocks $C_{\text {об.со. }}$ and $C_{\text {п.п. }}$, there is the cost flow of work results in the process of

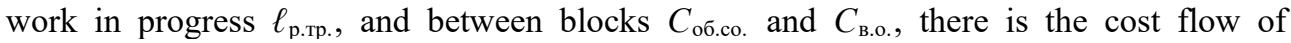
secondary waste $\ell_{\text {в... }}$, the resold part of which $\ell_{\text {в.о. }}{ }^{\mathrm{p}}$ can act as a cost flow for the production process input. At the exit of the production process, there is the cost flow of finished products of recycling sold by the consumer $\ell_{\text {п.п. }}$, as well as the cost flow of secondary waste, that are not sold in the process of repeated recycling $\ell_{\text {в.о. }}{ }^{\text {н.р. }}$. 
Based on the law of conservation of matter and energy for the above flow chart, we can draw up a cost balance equation for the production process of mineral raw material waste recycling for a period of time from $t_{n}$ to $t_{k}$ :

$$
C_{\text {пр.п. }}=C_{\text {п.тр. }}+C_{\text {об.со. }}+C_{\text {п.п. }}+C_{\text {в.о. }}+\int_{t_{n}}^{t_{k}} \ell_{\text {п.тр. }}{ }_{\text {вx }} d t+\int_{t_{n}}^{t_{k}} \ell_{3}^{\text {вx }} d t+\int_{t_{n}}^{t_{k}} \ell_{\text {p.с.. }}^{\text {вx }} d t-\int_{t_{n}}^{t_{k}} \ell_{\text {п.п. }}{ }^{\mathrm{p}} d t-\int_{t_{n}}^{t_{k}} \ell_{\text {в.о. }}^{\text {н.р. }} d t .
$$

In equation (3), when adding the input and exit cost flows to each block, flows $\ell_{\text {п.тр. }}, \ell_{\text {р.тр. }}, \ell_{\text {в.о. }}$, and $\ell_{\text {в.о. }}$ are mutually cancelled.

Based on (3), we can find the efficiency indicator of the waste recycling process expressed in terms of costs:

$$
K_{\text {эф }}=\frac{3_{\mathrm{T}}^{\text {Bर }}-3_{\text {пот. }}}{3_{\mathrm{T}}^{\text {Bx }}},
$$

where $3_{\mathrm{T}}{ }^{\mathrm{Bx}}$ is the costs of launching a specific recycling process, taking into account the cost of waste, the processing equipment, facilities, the cost of energy and labor force, the cost of work results, the finished products of recycling, in rubles; $3_{\text {пот. }}$ is the losses occurring in this production process and associated with the amount of secondary waste, the loss of energy, an insufficient use of means of labor, unproductive labor of workers, in rubles.

It is obvious that, in order to increase the efficiency of waste recycling processes, we need $K_{\ni ф} \rightarrow 1$. The analysis of equations (2) and (3) shows that such increase may be achieved through reducing the cost of equipment used, increasing the amount of waste recycled, decreasing the recycling process cost, provided that the quality of the recycling products meets the specified requirements. Improving the above indicators is possible subject to a correct selection of the nomenclature, design, and operating parameters of equipment used in process flow charts for recycling waste from nonmetallic quarries. Therefore, a very important issue in the system of launching an effective waste recycling process is the development of methods for assessing and selecting the parameters of the equipment used, in particular, classification and grinding machines.

High rates of development of all engineering industries require improvement of production at enterprises [20-34] with the solution a number of technological and organizational problems. The studies carried out at the MISiS proved the possibility of assessing the effectiveness of using various types of equipment of the same functional purpose by means of a complex indicator. Such indicators, calculated by combining several single indicators, are specific performance criteria to evaluate the equipment under study and to determine close-to-optimal parameters [35]. The use of specific performance criteria allows to develop processing methods and design schemes for machines that provide a positive effect by reducing the unit costs in the manufacture of various commercial products from mineral raw material waste.

Conclusions

1. In a formalized description of mechanical systems aimed at using waste as raw materials, waste recycling, and improving the environmental situation, we shall apply technological, economic, and environmental criteria.

2. The main efficiency indicator of waste recycling is the economic effect determined as the difference between the value of commercial products obtained from waste, the damage prevented, and the costs for obtaining such products, as well as the environment protection costs.

3. Determining the maximum profit when comparing various options of process flow charts for waste recycling, that are developed for small enterprises located in the waste accumulation areas, mainly depends on the costs of production processes and equipment, 
since the cost of mining, transportation, and environment protection activities are comparable with each other.

4. Increasing the efficiency of the waste recycling process is achieved by reducing the cost of the recycling process, the cost of equipment used in recycling, and by increasing the amount of waste recycled.

5. The quantitative and qualitative parameters of mineral raw material recycling can be improved by using the specific performance criteria that assess the degree of sophistication of the systems under study.

\section{References}

1. Razvitie promyshlennoj pererabotki tehnogennogo syr'ja v Rossii [The development of industrial processing of technogenic raw materials in Russia] Materials of the round table of the State Duma Committee on Natural Resources, Environment and Ecology (Moscow, 03.14.2016)

2. Issledovanie mineral'nogo syr'ya, otkhodov i vskryshnykh porod kar'erov s tsel'yu ispol'zovaniya ikh $v$ kachestve syr'evykh resursov i dlya zameny importiruemogo syr'ya $v$ stroitel'noi industrii i drugikh otraslyakh promyshlennosti g. Moskvy [Research of mineral raw materials, waste and overburden of quarries with the purpose of using them as raw materials and to replace imported raw materials in the construction industry and other industries of Moscow] Report of the Research Institute of the Central Regional Geological Center (Moscow, 1995)

3. B.N. Laskorin, L.A. Barskii, V.Z. Persits, Bezotkhodnaya tekhnologiya pererabotki mineral'nogo syr'ya [Waste-free technology for processing mineral raw materials] (Moscow, Nedra, 1984)

4. R.I. Kerimov, S.I. Shakhov, Metallurgist 64 (1-2), pp. 128-135 (2020) DOI: 10.1007/s11015-020-00974-1

5. O.A. Kobelev, V.A. Tyurin, Steel in Translation 37 (9), pp. 727-729 (2007) DOI: 10.3103/S096709120709001X

6. G.A. Pimenov, G.A. Kostyukov, P.S. Ryabov, V.D. Rogal', O.A. Kobelev, Tyazheloe Mashinostroenie 9, pp. 21-24 (1991)

7. B.A. Sivak, S.I. Shakhov, K.N. Vdovin, Y.M. Rogachikov, R.I. Kerimov, Metallurgist 63 (9-10), pp. 910-914 (2020) DOI: 10.1007/s11015-020-00909-w

8. S.I. Shakhov, K.N. Vdovin, R.I. Kerimov, Y.M. Rogachikov, D.S. Shakhov, Metallurgist 64 (5-6), pp. 410-417 (2020) DOI: 10.1007/s11015-020-01010-y

9. L.V. Sedykh, S.V. Albul, D.B. Efremov, M.A. Sukhorukova, IOP Conference Series: Materials Science and Engineering 971 (2), 022002 (2020) DOI: 10.1088/1757899X/971/2/022002

10. A.G. Nikitin, E.I. Demina, E.Y. Zhivago, L.T. Dvornikov, L.A. Saruev, IOP Conference Series: Materials Science and Engineering 411 (1), 012053 (2018) DOI: 10.1088/1757-899X/411/1/012053

11. A.Yu. Zarapin, A.I. Shur, N.A. Chichenev, Steel in Translation 29 (10), pp. 69-71 (1999)

12. S.M. Gorbatyuk, A.N. Pashkov, I.G. Morozova, O.N. Chicheneva, Materials Today: Proceedings 38, pp. 1889-1893 (2020) DOI: 10.1016/j.matpr.2020.08.581

13. V.V. Kukhar, Metallurgical and Mining Industry 7 (6), pp. 122-132 (2015)

14. L.A. Barskii, N.T. Glushkov, G.S. Gol'd, Ispol'zovanie ekonomiko-matematicheskikh modelei $v$ upravlenii $i$ planirovanii $v$ tsvetnoi metallurgii [The use of economic and 
mathematical models in management and planning in non-ferrous metallurgy] (Moscow, Metallurgiya, 1975)

15. A.S. Astakhov, Ekonomicheskaya otsenka zapasov poleznykh iskopaemykh [Economic evaluation of mineral reserves] (Moscow, Nedra, 1981)

16. V.T. Novikov, Oborudovanie i osnovy proektirovaniya sistem okhrany okruzhayushchei sredy [Equipment and basics of designing environmental protection systems] (Tomsk, TPU, 2003)

17. V.E. Vershin, Zakony energodinamiki pri reshenii zadach upravleniya ekonomicheskimi $o b^{\prime \prime}$ ektami [The laws of energy dynamics in solving problems of managing economic objects], Energy Approach to Systems Research 32, pp. 103-114 (2007)

18. A.D. Bardovskii, Razrabotka klassifikatsionno-izmel'chitel'nogo oborudovaniya i metoda ego otsenki pri pererabotke otkhodov nerudnykh kar'erov [Development of classification and grinding equipment and a method for its evaluation in the processing of non-metallic quarry waste] (Moscow, Moscow State Mining University, PhD dissertation, 2000)

19. A.D. Bardovskii, Model economicny procesow przerobki odpadow surocow mineralnych, Materials of the XXXV Symposium "Modeling in Mechanics" at the Silesian Polytechnic Institute (Poland, 1996)

20. A. Keropyan, A. Gerasimova, K. Goloshapov, MATEC Web of Conferences 129, 06009 (2017) DOI: 10.1051/matecconf/201712906009

21. A.A. Gerasimova, A.M. Keropyan, A.M. Girya, Journal of Machinery Manufacture and Reliability 47 (1), pp. 35-38 (2018) DOI: 10.3103/S1052618818010065

22. S.I. Shakhov, K.N. Vdovin, Steel in Translation 49 (4), pp. 261-264 (2019) DOI: 10.3103/S0967091219040120

23. A.G. Radyuk, A.A. Gerasimova, Metallurgist 62 (1-2), pp. 176-180 (2018) DOI: 10.1007/s11015-018-0641-y

24. L. Jiawen, S. Timushev, D. Klimenko, A. Krivenko, Proceedings of the 26th International Congress on Sound and Vibration, ICSV 2019 (2019)

25. A.M. Keropyan, D.A. Kuziev, A.E. Krivenko, Lecture Notes in Mechanical Engineering, pp. 703-709 (2020) DOI: 10.1007/978-3-030-22063-1_75.

26. D. Kouziyev, A. Krivenko, D. Chezganova, B. Valeriy, E3S Web of Conferences 105, 03014 (2019) DOI: 10.1051/e3sconf/201910503014

27. A.E. Krivenko, Z.K. Khanh, Gornyi Zhurnal 12, pp. 78-81 (2020) DOI: 10.17580/gzh.2020.12.18

28. S. Bratan, S. Roshchupkin, P. Novikov, Procedia Engineering 206, pp. 1419-1425 (2017) DOI: 10.1016/j.proeng.2017.10.655

29. Y. Gutsalenko, S. Bratan, S. Roshchupkin, V. Dyadichev, S. Menyuk, Materials Today: Proceedings 11, pp. 586-590 (2019) DOI: 10.1016/j.matpr.2019.01.033

30. I. Savchenko, A. Shapoval, A. Gurenko, IOP Conference Series: Materials Science and Engineering 969 (1), 012079 (2020)

31. A. Shapoval, I. Savchenko, O. Markov, Solid State Phenomena 316, pp. 928-935 (2021)

32. N. Hrudkina, L. Aliieva, O. Markov, I. Marchenko, A. Shapoval, P. Abhari, M. Kordenko, Journal of Enterprise Technologies 4/1(106), pp. 55-62 (2020)

33. M.G. Naumova, I.G. Morozova, P.V. Borisov, Materials Today: Proceedings 19, pp. 2405-2408 (2019) DOI: 10.1016/j.matpr.2019.08.044

34. V.E. Kondratenko, V.V. Devyatiarova, S.V. Albul, D.S. Kartyshev, IOP Conference Series: Materials Science and Engineering 971 (5), 052037 (2020) DOI: 10.1088/1757899X/971/5/052037 
35. B.E. Gorskii Dinamicheskoe sovershenstvovanie mekhanicheskikh system [Dynamic improvement of mechanical systems] (Kiev, Tekhnika, 1987) 